\section{Measurement of Osmotic Pressure in Single Cells}

A CRYOSCOPIC method of measuring the osmotic pressures of very small quantities of fluid $\left(10^{-6}\right.$ c.c.) has recently been described by Ramsay. The principle of the method is to place the liquid in a quartz capillary and freeze it by immersion in solid carbon dioxide. The system is then warmed and the temperature at which the smallest observable ice crystal remains in equilibrium with the liquid is noted. This constitutes the freezing-point depression. This method can be used for measuring the osmotic pressure of single cells and strips of muscle 50-200 $\mu$ in diameter, material of these dimensions being sufficiently transparent for the ice crystals to be clearly seen.

When the osmotic pressure of a muscle fibre is to be measured, the muscle is lightly blotted with filter-paper and teased to the required size under paraffin. It is then drawn up into a quartz tube $200-400 \mu$ in diameter. Comparisons of the freezingpoint depressions of blood and muscle of Mytilus edulis and of sea water are given in Table 1 .

Table 1. $\Delta^{\circ} \mathrm{C}$.

\begin{tabular}{|l|cccccc|}
\hline Exp. No. & 1 & 2 & 3 & 4 & 5 & 6 \\
\hline Sea water & $2 \cdot 070$ & $2 \cdot 080$ & $2 \cdot 075$ & $2 \cdot 080$ & $2 \cdot 080$ & $2 \cdot 080$ \\
Blood & $2 \cdot 080$ & $2 \cdot 090$ & $2 \cdot 070$ & $2 \cdot 080$ & $2 \cdot 080$ & $2 \cdot 075$ \\
Muscle* & $2 \cdot 070$ & $2 \cdot 080$ & $2 \cdot 080$ & $2 \cdot 080$ & $2 \cdot 050$ & $2 \cdot 085$ \\
\hline
\end{tabular}

In the case of single cells, the material is placed under paraffin in a watch glass. The amount of fluid around the cell should be minimal, any surplus being removed with a pipette. The freezing-point depression of the unfertilized eggs of Psammechinus miliaris was examined in this way, parallel determinations being made on sea water and eggs over a period of two hours, during which the sea water was allowed to become more concentrated by evaporation. The eggs remained fertilizable during this period. The results of the measurements are given in Table 2 .

Table 2. $\triangle^{\circ} \mathrm{C}$

\begin{tabular}{|c|c|}
\hline $\begin{array}{c}\text { Unfertilized eggs of } \\
\text { Psammechinus miliaris }\end{array}$ & Sea water (Millport) \\
\hline 1.79 & $1 \cdot 79$ \\
1.82 & $\overrightarrow{2}$ \\
1.87 & $1 \cdot 86$ \\
1.90 & 1.92 \\
1.91 & 1.90 \\
\hline
\end{tabular}

The results in Table 2 are compatible with Lucké's ${ }^{2}$ measurements of the permeability of the unfertilized eggs of Arbacia punctulata. Using Lucké's figure of $0.1 \mu^{3} / \mu^{2} / \mathrm{atm} . / \mathrm{hr}$., calculations show that the freezing point of the unfertilized eggs should be $0.005^{\circ} \mathrm{C}$. lower than that of the sea water under the conditions of this experiment.

I am indebted to Dr. J. A. Ramsay for the use of his apparatus, to Lord Rothschild for providing the unfertilized sea urchin eggs, and to the Department of Scientific and Industrial Research for financial assistance.

Department of Zoology,

University of Cambridge. Feb. 9.

${ }^{1}$ Ramsay, J. A., J. Exp. Biol., 26, 57 (1949).

Lucké, B., and Harvey, E. N., J. Cell. Comp. Physiol., 5, 473 (1935).

\section{A Predacious Amœboid Organism destroying Larvæ of the Potato Root Eelworm and other Nematodes}

WhILE screening a number of chemicals for their nematicidal action on the cysts of the potato root eelworm, Heterodera rostochiensis Wollenweber, one of us (A. Ph. W.) discovered an amcboid organism which attacks the larvæ of this nematode. The organism was encountered in the form of brownish spherical, single-walled hypnocysts ${ }^{1} 25-40 \mu$ in diameter, firmly sticking to the surface of the cysts of Heterodera. If larvæ leave the cyst subsequent to treatment with an aqueous solution of potato root diffusate, or if larvæ suspended in tap water are added, creeping trophic forms emerge from the hypnocysts. The phenomenon can be best observed if the bottom of the container is not too smooth. Probably for this reason very good results were obtained in the small cavities drilled in clear plastic, in which the observations were carried out. Glass containers or slides and hanging-drop preparations were not so satisfactory.

The creeping trophic form consists of a thin body of colourless, uniformly granular protoplasm, branching and anastomosing, slowly and incessantly streaming, capable of division by plasmotomy, and of fusion with other individuals. Nuclei have not been observed. In tap water numerous minute contractile vacuoles are visible. The size of the trophic form ranges from $40 \mu$ to $300 \mu$ from end to end in the completely extended condition. Fig. 1 shows a creeping trophic form. Under less favourable conditions (on glass or in a hanging drop), a globular or irregularly angular trophic form emerges from the hypnocyst, furnished with numerous finely radiating pseudopodia.

The trophic form attacks the larvæ in the following manner. After adhering to a larva near its head or tail (Fig. 2), it engulfs the prey completely within a short time $(20 \mathrm{~min}$. to $2 \mathrm{hr}$.). The motionless larva is then seen lying in the protoplasm of the organism, which at this time is comparatively clear. Sometimes one or more other larvæ are caught in this sticky mass. The successful attack on three or even five larvæ simultaneously has been observed. After a time, a cyst wall is secreted and digestion starts. Initially, the form of the digestive cyst $^{2}$ is strongly dependent on the form of the prey (Fig. 3) ; but after one or two days the cyst becomes more globular. Some days later, no trace of the ingested larva(e) can be seen in the rather homogeneous protoplasm. In the centre a large excretion vacuole is developed. The protoplasm later detaches itself from the delicate cyst wall and creeps out as a large amcoboid mass (diameter up to $300 \mu$ ), leaving the contents of the excretion vacuole behind.

If the supply of larvæ is exhausted, the protoplasmatic mass develops long rhizopodia, which can fuse with each other and with the rhizopodia of other individuals. Thus a freely branching network covering the whole bottom of the plastic container (diameter 5 $\mathrm{mm}$.) may be formed. Neither distinct nuclear centres nor any differentiation of the protoplasm can be seen at this stage (at least as observed in unstained living specimens). Eventually, a concentration of protoplasm at the junctions of the rhizopodia takes place. The rhizopodia stretch and finally snap like taut strings at different places. In this way a number of creeping forms exactly like the form already described originate from the amceboid mass via the reticulate 